Tomasz Ferenc

\title{
Bohater, wróg, zdrajca - amerykańskie i niemieckie plakaty z okresu II wojny światowej ${ }^{1}$
}

W filmach propagandowych produkowanych w USA przed przystąpieniem tego państwa do II wojny światowej ujawniły się dwa główne wątki (Lazarsfeld, Merton 2002: 553). Pierwszy ukazywał okrucieństwo hitlerowców, to jak traktowana jest ludność cywilna, jak palone są całe miasta i wsie, jak niszczony jest cywilizacyjny dorobek Europy. Wątek ten miał wywołać poczucie zagrożenia oraz wzbudzić w społeczeństwie poparcie dla rządowych planów dotyczących wypowiedzenia wojny Niemcom. Drugi wątek pokazywał nazistowską maszynę wojenną w akcji; najnowocześniejszą jak na owe czasy, doskonale wyszkolona, doświadczoną i bitną armię, która podbiła już całą Europę, część Afryki i Azji. Ukazywano także ogromną liczbę żołnierzy i masę sprzętu bojowego. Po przeprowadzeniu badań nad recepcją filmów okazało się, że duch bojowy wśród tych, którzy je obejrzeli był procentowo mniejszy niż wśród tych, którzy filmów nie widzieli. Co się stało? Pytali zatrwożeni twórcy propagandowych obrazów. Okazało się, że dwa główne wątki konstruujące filmy oddziaływały na widzów sprzecznie. Agresja i złość wzbudzana wątkiem pierwszym studzona była wątkiem drugim, który wywoływał strach. Pojawiła się obawa dotycząca szans Ameryki w zbrojnej konfrontacji z faszystowską potęgą militarną. W owym czasie lądowe siły zbrojne USA faktycznie nie mogły równać się z armią nie-

${ }^{1}$ Pierwsza wersja tekstu została opublikowana w książce Sztuki wizualne jako nośniki ideologii, red. M. Lisicki, (2009), Toruń: Wydawnictwo Adam Marszałek. 
miecka, pomimo to wielu Amerykanów było jednak przekonanych, że to właśnie Stany mają największy potencjał militarny. Filmy boleśnie uświadamiały, że przekonanie o własnej potędze jest błędne, a także, że pokonanie państw Osi wymagać będzie ogromnego wysiłku całego społeczeństwa. Autorów filmów spotkała chyba najgorsza rzecz, jakiej doświadczyć może twórca propagandy (ale i wszelkiego typu reklamy), czyli tzw. efekt bumerangowy. Mówiąc najkrócej, zetknęli się z sytuacja, $\mathrm{w}$ której ludzie poddani zabiegom propagandy reagują na nią odmiennie niż było to zamierzone. W przypadku omawianych filmów doszło do strukturalnego efektu bumerangowego, czyli sprzecznego oddziaływania na siebie różnych wątków przekazu w tym samym elemencie propagandowym.

Może się okazać, iż wątek opisujący budzącą strach potęgę hitlerowską może przeciwdziałać wzbudzającemu agresję wątkowi okrucieństwa hitlerowców. Wrogie uczucia nie muszą się zatem przekształcić w realistyczne pragnienie, by naród amerykański przystą̧ił do konfliktu zbrojnego (Lazarsfeld, Merton 2002: 554).

Do wojny, która toczyła się gdzieś daleko i do pewnego momentu nie zagrażała amerykańskim interesom.

Propaganda jest nieodłącznym elementem polityki wojennej każdego państwa. Zdefiniujmy ją za Aronsonem i Pratkanisem jako zestaw działań obejmujących

zręczne posługiwanie się obrazami, sloganami i symbolami, odwołujące się do naszych uprzedzeń i emocji; jest komunikowaniem pewnego punktu widzenia mającym na celu skłonienie odbiorcy do dobrowolnego przyjęcia tego punktu widzenia za swój (2003: 17).

W zależności od tego, czemu propaganda służy, możemy mówić o jej pozytywnym lub negatywnym charakterze. Obok filmów ważną rolę odgrywają audycje radiowe, publikacje prasowe, przemówienia, wiece, ulotki i, najbardziej interesujące nas w tym przypadku, plakaty. Do ich tworzenia powoływane były całe sztaby plastyków i teoretyków społecznej perswazji. Jak zrobić plakat, który pomoże wygrać wojnę? Jak nakłonić młodych ludzi, by szli walczyć i ginąć w odległej Europie? Jak skłonić naród do intensywnej pracy na rzecz zbrojeń? Specjalnie przez rząd powołana komisja (Office of Facts and Figures) miała znaleźć odpowiedzi na te pytania. Pamiętajmy, że groźba bumerangu czyhała także na plakacistów. A zatem zdaniem komisji najbardziej efektywny plakat wojenny 
Bohater, wróg, zdrajca - amerykańskie i niemieckie plakaty...

powinien bezpośrednio odwoływać się do emocji za pomocą realistycznych obrazów, z zachowaniem fotograficznej wręcz dbałości o detale. Plakaty humorystyczne lub przepełnione symbolami miały za to okazać się znacznie mniej skuteczne, nie wzbudzać entuzjazmu, a co najważniejsze - nie przykuwać uwagi tak intensywnie jak obrazy realistyczne. Specyficzną i ważną rolę w obrazowaniu wroga odgrywała karykatura, której główne zadania polegały na zdehumanizowaniu obrazu przeciwnika (Żyd czy bolszewik w propagandzie faszystowskiej), ale także poprzez ośmieszenie miały uczynić go mniej przerażającym i niebezpiecznym niż w rzeczywistości (Hitler na amerykańskich plakatach). Wykorzystanie zbyt wielu symboli powoduje, że mogą zostać one źle zinterpretowane. Jeśli zatem odwoływano się do nich, to tylko do tych powszechnie znanych i akceptowanych przez cały naród. W przypadku USA był to, i nadal jest, gwiaździsty sztandar, w faszystowskich Niemczech stała się nim wszechobecna swastyka. Do podobnych wniosków doszli bowiem twórcy nazistowskich posterów. Repertuar symboli i przekaz, zawarty $\mathrm{w}$ ich plakatach, jest dość ograniczony. W strukturze plakatu wojennego nie ma miejsca na zbędne subtelności, przekaz musi być prosty, jednoznaczny i wywołujący lub przynajmniej wzmacniający określone pożądane reakcje.

\section{Materiał badawczy i metoda analizy}

Jako materiał badawczy wybrałem dwa zestawy składające się z 30 plakatów niemieckich i 30 amerykańskich. Dostęp do tego typu materiałów zapewniają liczne strony internetowe, reprezentujące instytucje badawcze, prywatne witryny kolekcjonerów oraz strony komercyjne, sprzedające plakaty wojenne. Starałem się wybrać te plakaty, które pojawiały się najczęściej, na kilku stronach jednocześnie. Dwiema podstawowymi witrynami, z których czerpałem materiał do analizy, były strona narodowego archiwum amerykańskiego (http://www.archives.gov) oraz strona poświęcona nazistowskiej propagandzie (http://www.calvin. edu/academic/cas/gpa/posters2.htm). Analizując wybrane plakaty, posłużyłem się techniką analizy treści, która wydała mi się najlepsza do pracy nad zestawem obrazów. Jej istota polega na sprawdzaniu częstotliwości występowania poszczególnych elementów w dokładnie zdefiniowanej grupie (zestawie) obrazów. Każdy z kolejnych etapów tego procesu wią- 
że się z wymaganiami, których przestrzeganie jest koniecznym warunkiem osiągnięcia "zadowalającego", końcowego rezultatu (Rose 2006: 56). Badanie przebiegało $\mathrm{w}$ czterech etapach. Pierwszy, już opisany, polegał na wyborze interesującego i spójnego zbioru plakatów wedle sprecyzowanych reguł. Wymaga to dokładnego określenia zasad doboru próby, tego co i wedle jakich reguł zostaje włączone do badanego przez nas zbioru$^{2}$. Drugi etap polega na wygenerowaniu kategorii służących do kodowania. Jest to kluczowy moment $\mathrm{w}$ całym badawczym procesie. Konieczne zatem było opracowanie zestawu kategorii służących do opisu każdego z obrazów. Generowanie następuje w wyniku wstępnej analizy materiału, która powinna zakończyć się wyszczególnieniem wszystkich możliwych kategorii analitycznych, co należy podkreślić, jest zadaniem niezwykle trudnym. Zestaw kategorii do kodowania powinien być wyczerpujący, czyli uwzględniać każdy aspekt, którego dotyczy badanie, wyłączny, co oznacza, że poszczególne kategorie nie mogą się ze sobą pokrywać oraz musi być rozjaśniający, co oznacza, że kategorie muszą przynieść takie przełamanie obrazowości, które okaże się w rezultacie interesujące analitycznie i koherentne (Rose 2006: 60). Trzeci etap to kodowanie obrazów. Wyznaczone uprzednio kategorie muszą być jednoznaczne. Kiedy rozpoczyna się faza właściwego kodowania, każdy obraz musi zostać dokładnie przeanalizowany. Do każdego z nich należy dołączyć właściwe kody. Pierwszym, wstępnym krokiem ku opracowaniu danych jest zliczenie częstotliwości występowania danych kategorii. Już ta prosta operacja pozwala na dostrzeżenie pewnych tendencji i na formułowanie wniosków. Kolejnym krokiem może być eksplorowanie zależności między różnymi kategoriami i poszukiwanie wzajemnych powiązań. Proces ten można rozpocząć od dwóch kategorii po to, aby później uruchomić kolejne i tym sposobem analizować łańcuch zależności pomiędzy różnymi elementami. Opisana metoda stała się dla mnie wzorem organizowania pracy z materiałem, można było jednak z pewnością wykorzystać ją bardziej ortodoksyjnie.

Zamykając kwestie metodologiczne należy wspomnieć o zaletach i wadach zastosowanej przeze mnie metody badawczej. Stosując ją możemy pracować na dużych zbiorach obrazów i wprowadzać precyzyjne

${ }^{2}$ G. Rose w swojej książce opisuje kilka metod dobierania próby, podkreślając, że musi być ona reprezentatywna i uwzględniać wszystkie możliwe warianty elementów występujących w danym zbiorze. Książka Rose została w roku 2010 wydana przez PWN, w tym tekście korzystano z oryginalnej wersji anglojęzycznej (2006). 
Bohater, wróg, zdrajca - amerykańskie i niemieckie plakaty...

kategorie analityczne porządkujące opracowywany materiał. Badaczowi daje to szansę ogarnięcia materiału, usystematyzowania go i sformułowania wniosków końcowych. Ale ten typ analizy koncentruje się jedynie na samym obrazie, pozostawiając poza obszarem penetracji procesy jego wytwarzania i funkcjonowania społecznych obiegów obrazów. Dogłębna analiza obrazów wymagałaby zatem zastosowania także innych technik analizy, jak chociażby semiotyki, psychoanalizy czy analizy dyskursu.

Wstępna analiza dwóch zestawów plakatów pozwoliła na wyodrębnienie następujących kategorii: 1) płci (obecność i sposób prezentacji kobiet i mężczyzn na plakatach), 2) wieku (dorośli, młodzież i dzieci - role przypisane poszczególnym kategoriom wiekowym), 3) rasy (jak ukazywane są i czemu służą odmienności rasowe), 4) przywództwa (obecność wodzów na plakatach i sposób ich pokazywania), 5) symboliki (jakie symbole występują na plakatach, jak są wykorzystywane), 6) sposobów ukazywania „siebie” i wroga, 7) metod łączenia obrazu z tekstem (jakie treści werbalne pojawiają się na plakatach i w jaki sposób), 8) obecności stereotypów (technik manipulowania wrażeniami odbiorcy poprzez uproszczenia), 9) dominującej kolorystyki (formalna strona przedstawień). Kategoria siódma przenosi poziom analizy z kodu wizualnego na kod językowy. Oba poziomy pozostają jednak nierozerwalnie związane i muszą być analizowane kompleksowo, ponieważ plakat jest specyficzną formą werbalno-obrazowej wypowiedzi.

\section{Bohaterowie plakatowych wojen}

Głównym obiektem przedstawień zarówno amerykańskich, jak i niemieckich plakatów wojennych jest człowiek. Istota ludzka wpleciona w tryby militarnej machiny staje się głównym nośnikiem informacji, perswazji, przestrogi. Z plakatów spoglądają na nas realistycznie namalowani ludzie. Czy będzie to żołnierz, robotnik, młodzieniec, czy dziecko, to zazwyczaj do czynienia mamy z bardzo precyzyjnym przedstawianiem postaci. Oczywiście celem takiego przedstawiania jest umożliwienie jak najłatwiejszej identyfikacji odbiorcy z ukazywaną postacią. To nie abstrakcyjna istota, ale jeden $z$ nas. Jeden, bo łatwiej się identyfikować z konkretną osobą niż z grupą lub tłumem. W przypadku amerykańskich plakatów pojawiają się nawet prawdziwi żołnierze. Na przykład afroamerykański szeregowy Joe Louis przemawia z plakatu: „Mamy zamiar wykonać naszą robotę... i wygramy bo jesteśmy po stronie Boga". Na 
plakacie zaś widzimy idącego do ataku na bagnety żołnierza. Inny przykład to portret, także czarnoskórego, odznaczonego medalem marynarza Dobie Millera.

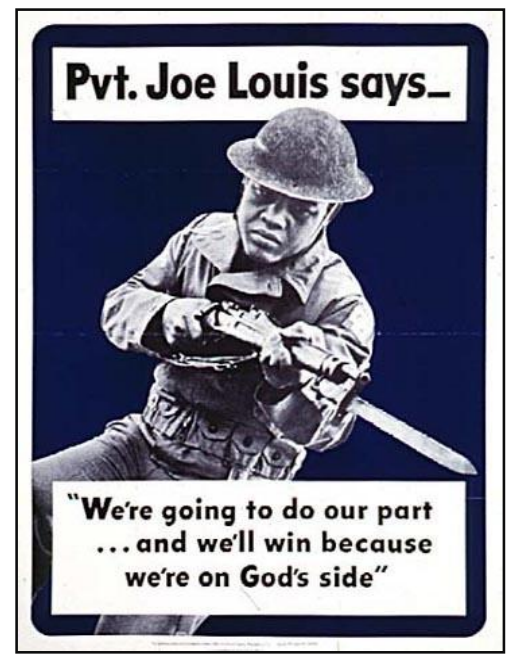

Plakat 1

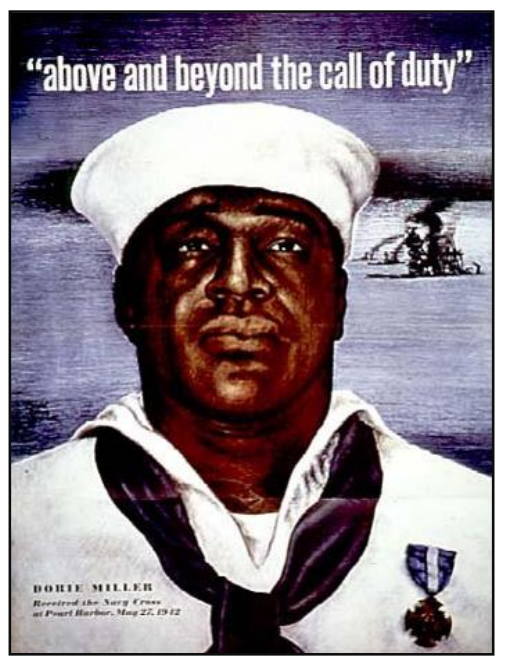

Plakat 2

Nad głową marynarza umieszczono napis „obowiązek ponad wszystko". Propaganda potrzebuje bohaterów, w tym przypadku nie bez znaczenia pozostaje kolor skóry i budowanie poczucia jedności narodowej wszystkich mieszkańców USA. Nieco inaczej wygląda obecność konkretnych istniejących postaci na plakatach niemieckich. Tu jest miejsce przede wszystkim dla jednego człowieka, dla wodza. Hitler pojawiał się na wielu plakatach, a jednym z najliczniej reprodukowanych był utrzymany w ciemnobrązowej tonacji portret Führera z napisem „Adolf Hitler jest zwycięstwem".

Skupianie się na wodzu oraz anonimowych masach wydaje się charakterystyczne dla dyktatur, $\mathrm{w}$ demokracjach przywódca, choć równie ważny w czasie konfliktów, nie staje się zazwyczaj pierwszoplanową i niemal jedyną rozpoznawalną postacią kampanii propagandowych. Plakaciści z obu krajów posługiwali się zarówno wizerunkami mężczyzn, jak i kobiet. Oczywiście fundamentalną rolą mężczyzny była walka na froncie. Ukazuje się zatem szereg plakatów przedstawiających reprezentantów przeróżnych formacji - marynarki, lotnictwa, piechoty. Obok żołnierzy pojawiają się także wizerunki robotników, traktowanych jako 
Bohater, wróg, zdrajca - amerykańskie i niemieckie plakaty...

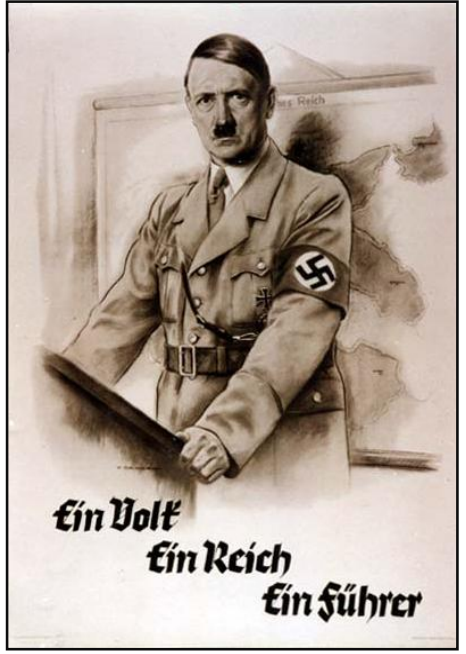

Plakat 3

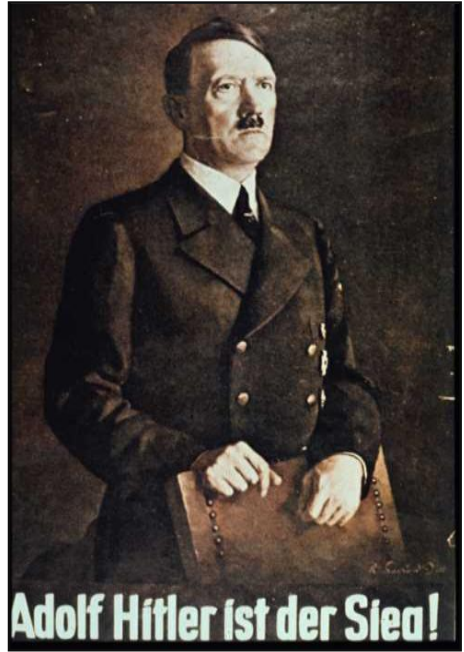

Plakat 4

bohaterowie drugiej linii frontu. Od ich wydajności uzależnione jest bowiem skuteczne funkcjonowanie wojennej machiny, a w rezultacie ostateczne zwycięstwo. Znamienny wydaje się tutaj niemiecki plakat ukazujący robotnika podającego wiązkę granatów idącemu do boju żołnierzowi (plakat 6). Obaj mają podwinięte rękawy swoich uniformów - zakasane do ciężkiej, żmudnej i wymagającej ofiar pracy.

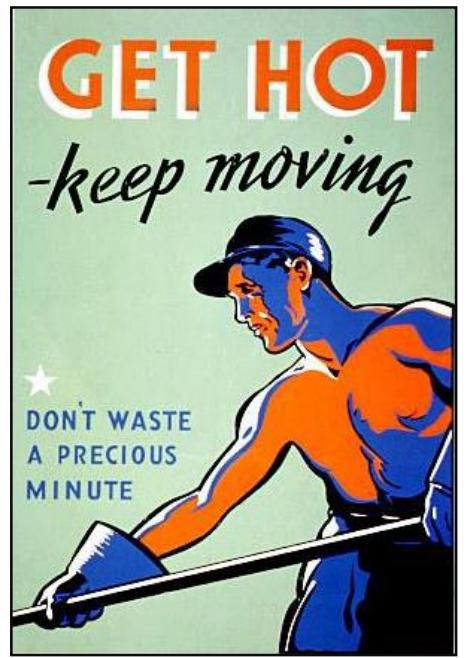

Plakat 5

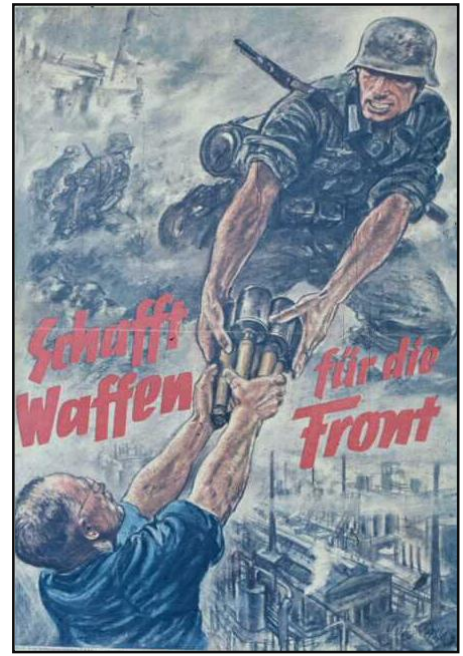

Plakat 6 
$\mathrm{Z}$ kolei na posterze $\mathrm{z}$ USA widzimy pochylonego $\mathrm{w}$ trudzie robotnika z zalecaniem "ruszaj się - nie trać cennych minut” (plakat 5). Postacie $\mathrm{z}$ wojennych plakatów dokładnie odpowiadają dominującym w czasach nowoczesnych wzorcom kształtowania ludzkich jednostek opisanych przez Z. Baumana (1995: 53-54). Przeważający typ wytwórcy i wojskowego charakteryzowały cechy uwidocznione na plakatach. Po pierwsze człowiek miał być przede wszystkim nośnikiem kinetycznej energii, służącej do budowania lub niszczenia. Ten projekt osobowościowy realizował się głównie $\mathrm{w}$ walce lub $\mathrm{w}$ produkcji. Po drugie jednostka musiała być zdyscyplinowana, tak aby jej energię można było odpowiednio ukierunkować. Plakaty można rozpatrywać jako jedną $\mathrm{z}$ form przynaglania jednostki, dyscyplinowania jej, przypominania o konieczności nieustannego podejmowania monotonnych działań. Po trzecie, pisze Bauman, jednostka nie stanowi sama w sobie całości zdolnej przetrwać i funkcjonować, musi być dopasowana i powiązana $\mathrm{z}$ innymi jednostkami. Wydaje się, że czas wojny szczególnie sprzyja tej postawie integracji $\mathrm{w}$ walce, $\mathrm{w}$ zjednoczeniu się przeciw wspólnemu wrogowi. Tylko taka postawa stwarza szansę na zwycięstwo. Nie dziwi zatem umieszczanie na posterach haseł typu: „United we win” czy „Alle Zehnjahrigen zu die HJ” („,wszystkie dziesięciolatki do Hitlerjugend"). I czwarta cecha, także widoczna na omawianych plakatach. Idealny wzór wytwórcy - wojskowego musiał być okazem zdrowia, krzepy fizycznej, musiał posiadać silne ciało pełne energii. Tylko taki osobnik był $\mathrm{w}$ stanie sprostać powierzonym mu zadaniom. Na plakatach oznaczało to ukazywanie "swoich" - zarówno mężczyzn, kobiet, jak i dzieci - zgodnie z idealnym wzorcem. Dokładnie odwrotnie ukazywano wroga - jako istotę wątła, fizycznie zdegenerowana, nieatrakcyjną wizualnie, brzydką. Schemat ten powielano zarówno w propagandzie niemieckiej, jak i amerykańskiej.

$\mathrm{Na}$ drugiej linii walki szczególną rolę miały do odegrania kobiety. Pojawiają się zatem $\mathrm{w}$ mundurach służb pomocniczych jako robotnice w fabrykach broni, zajmują się rola, chronią dzieci, namawiają do kupowania talonów (obligacji) wojennych. Ciekawym przykładem jest amerykański plakat ukazujący na tle narodowych barw młodą kobietę nad maszyną do pisania. Hasło jak zwykle nie jest skomplikowane: „Zwycięstwo czeka na Twoje palce” i wyjaśnienie poniżej „wujek Sam potrzebuje stenografistek!" (plakat 7). Kobiety w czasie wojny totalnej muszą zaangażować się podobnie jak mężczyźni, ich praca jest konieczna do obsłużenia ogromnego produkcyjno-biurokratycznego zaplecza rozgrywającej 
się wojny. Wyraźnie widać to na plakacie ukazującym kobietę pracującą przy montażu kabiny samolotu bojowego z wymownym hasłem „Im więcej kobiet w pracy, tym szybciej wygramy" (plakat 11).

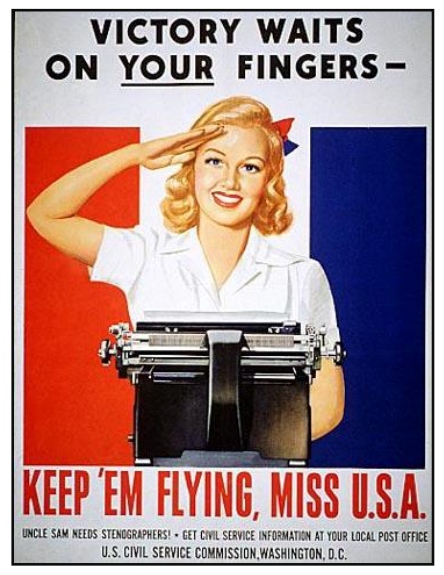

Plakat 7

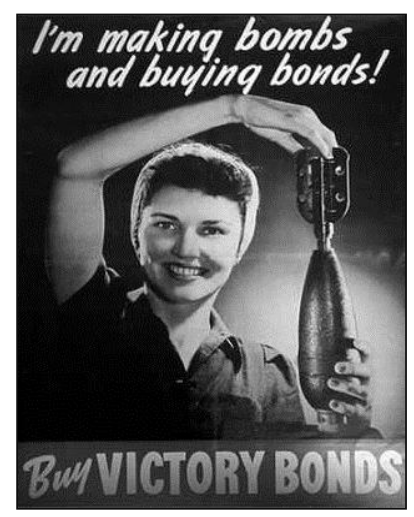

Plakat 10

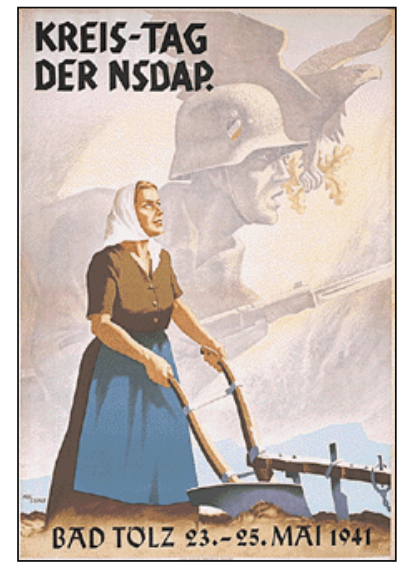

Plakat 8

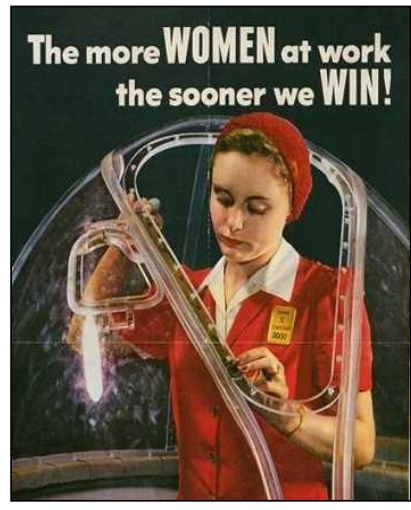

Plakat 11

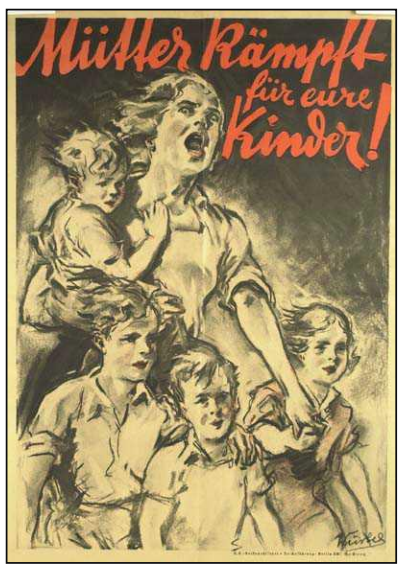

Plakat 9

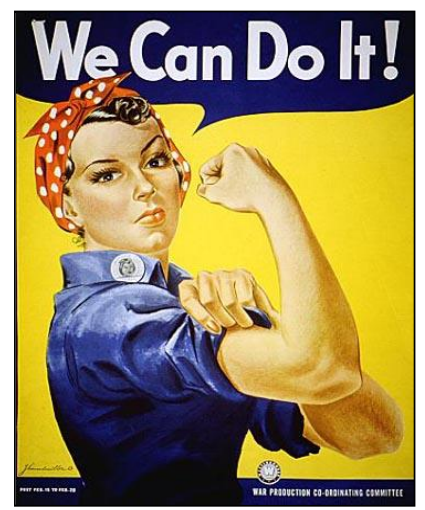

Plakat 12

Ale wizerunek kobiety pojawia się także w innym kontekście. Na wielu plakatach zarówno niemieckich, jak i amerykańskich staje się ona ucieleśnieniem bezmyślności, trwogi, niezdolności do działania. Na jednym z plakatów (plakat 13) pod wizerunkiem kobiety tulącej do piersi listy od swego ukochanego umieszczono napis: „Tęsknota nie sprowadzi go do domu wcześniej. Postaraj się o »wojenną" pracę" (org. „war job”). Ale to tylko łagodne napomnienie $\mathrm{w}$ porównaniu z plakatem przestrzegającym 
przed nierozważnymi rozmowami. Istnieje wiele niemieckich i amerykańskich posterów ostrzegających przed skutkami zdradzania tajnych informacji. Na jednym z nich (stylizowanym na list gończy) pojawia się wizerunek kobiety poszukiwanej za nierozważne rozmowy, które kosztowały życie (plakat 14). Ten motyw ilustrowano często dosadnymi, dramatycznymi obrazami. Plakaty miały uwrażliwić społeczeństwo na to, co i do kogo się mówi. Wojna nie toczy się jedynie gdzieś w odległej Europie lub na wodach Pacyfiku, wojna jest wszędzie, przebiega na wielu liniach frontu. Wróg wewnętrzny, szpieg lub zdrajca nieustannie łowią cenne informacje. $\mathrm{O}$ takich niebezpieczeństwach napominały liczne plakaty wojenne. Wykorzystanie wizerunku kobiety $\mathrm{w}$ tym przypadku jest jednym $\mathrm{z}$ wielu przejawów stereotypizacji, na której opiera się wojenna propaganda.

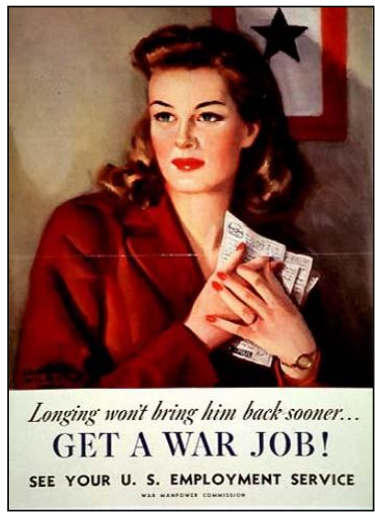

Plakat 13

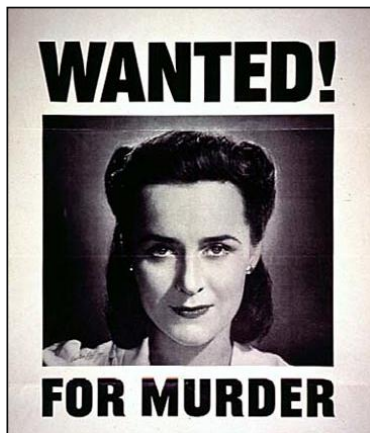

Her careless talk cosis lives

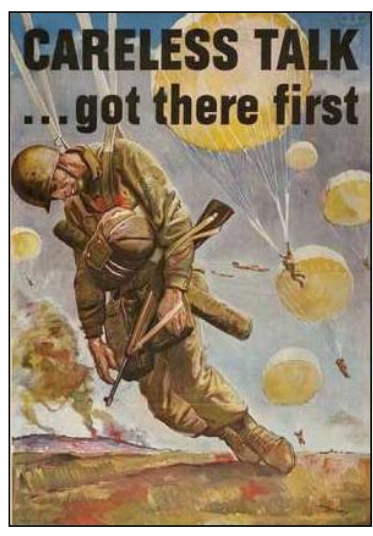

Plakat 15

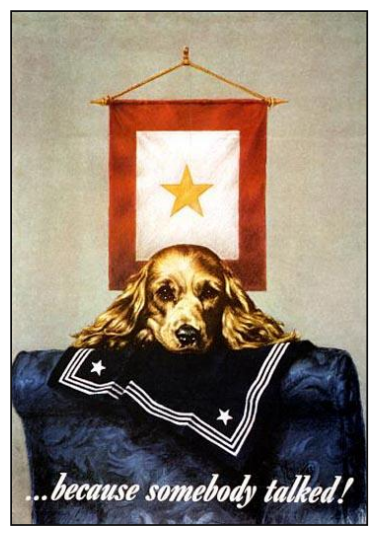

Plakat 16

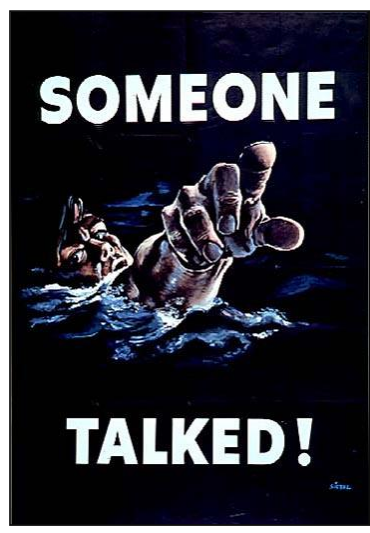

Plakat 17 
W bogatej ikonografii wojennych plakatów znajdujemy także wizerunki dzieci. Na faszystowskich posterach ujawniają się dwa motywy. Pierwszy ukazuje dzieci jako obiekt troski i zainteresowania wodza. Dzieci i młodzież mają korzystać z krynicy mądrości, jaką jest Führer. Drugi wątek dotyczy wstępowania i przynależności chłopców oraz dziewcząt do młodzieżowych organizacji faszystowskich, takich jak Hitlerjugend. Wykorzystywanie wizerunków dzieci miało inne zadanie w III Rzeszy niż w USA. Chłopcy mieli stać się żołnierzami, dziewczęta szykowano do roli matek i żon, niemieckich kapłanek rasy, opiekunek rodziny i narodu. Niemcy prowadzące wojnę na wielu frontach, od klęski pod Stalingradem musiały angażować do walki coraz młodsze roczniki. Propaganda kładła silny nacisk na udział całego społeczeństwa w wojennym wysiłku. Po wspomnianej klęsce, 18 lutego 1943 r. Goebbels podkreślał konieczność prowadzenia wojny totalnej, która jest sprawą całego narodu. "Alert musi ogarnąć cały kraj. Jak kraj długi i szeroki, prace podejmą miliony rąk" (Goebbels 2006: 126). Będą to ręce kobiet, młodzieży i dzieci - wojna totalna obejmie całe społeczeństwo.

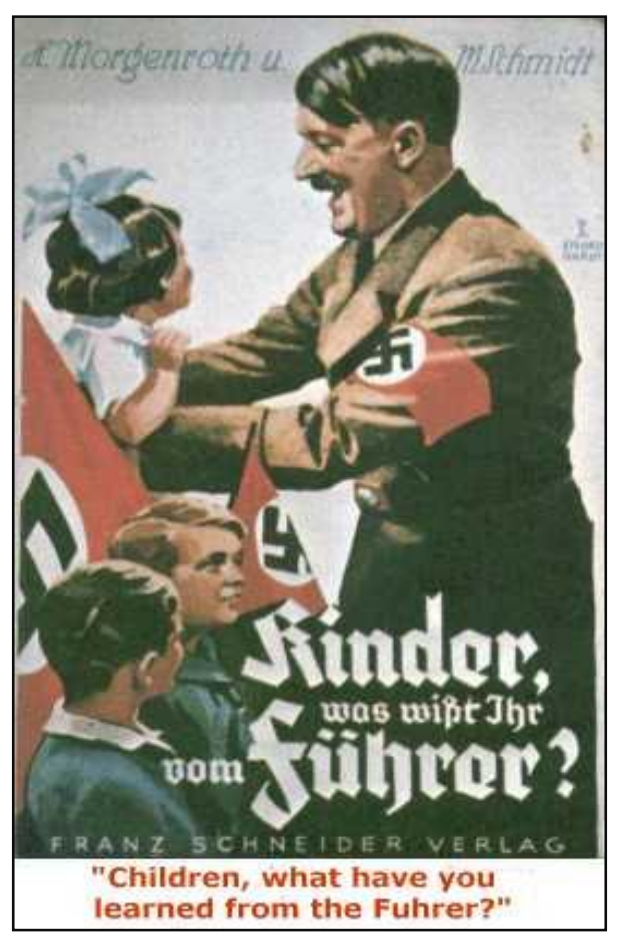

Plakat 18

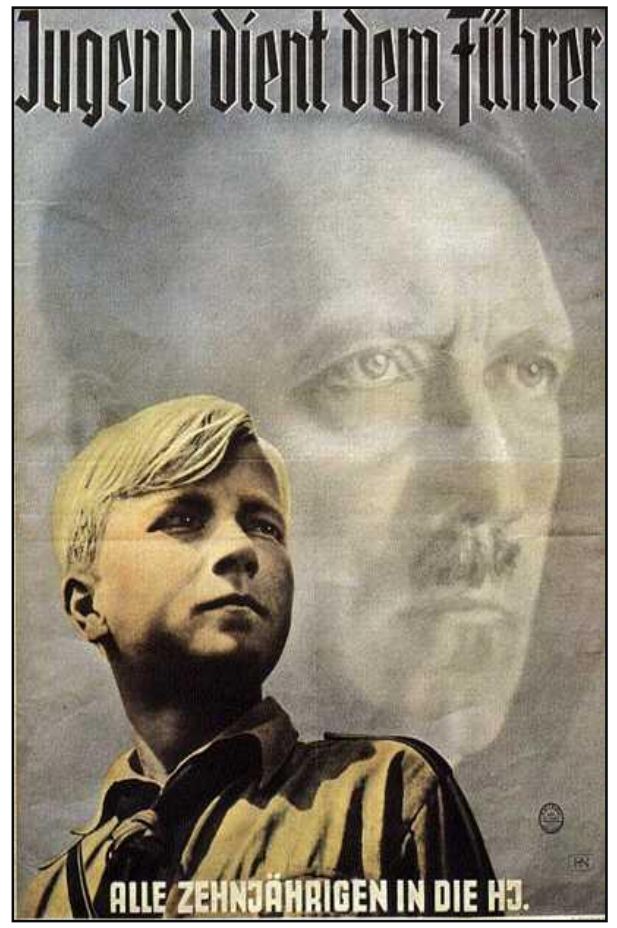

Plakat 19 


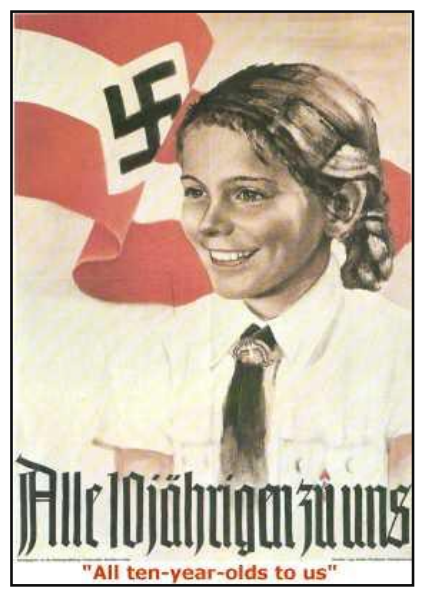

Plakat 20

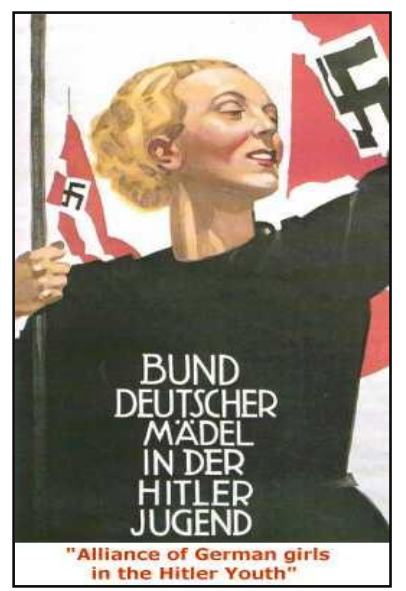

Plakat 21

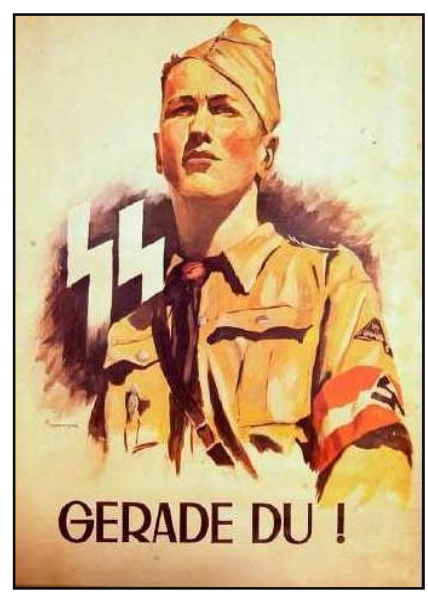

Plakat 22

W propagandzie amerykańskiej także pojawiają się wizerunki dzieci. Nie ma tu jednak nakłaniania ich do angażowania się $\mathrm{w}$ organizacje paramilitarne, dzieci ukazywane są jako największe dobro narodu, jako bezbronne istoty, które trzeba chronić.

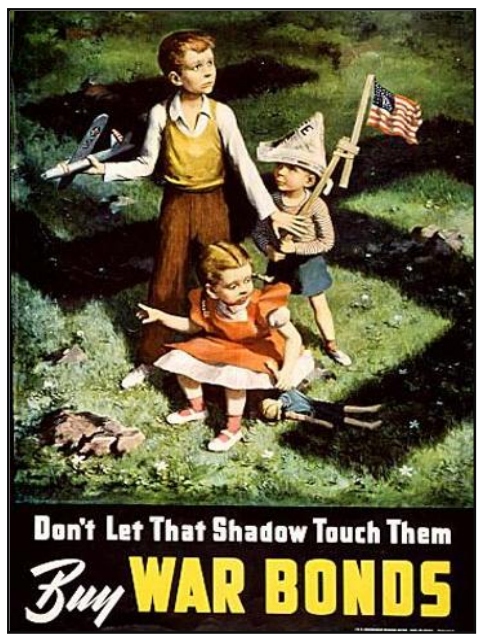

Plakat 23

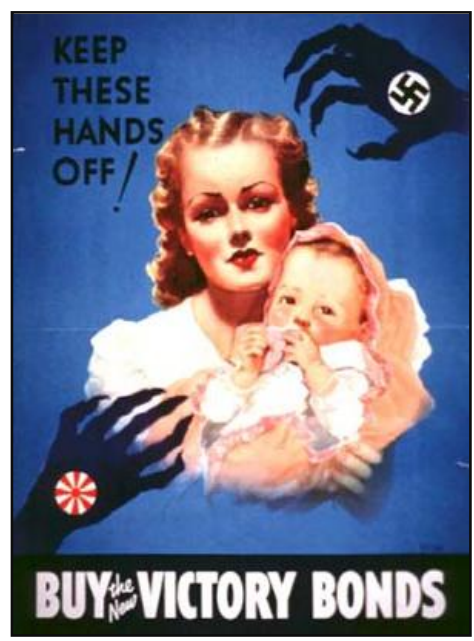

Plakat 24

Przy okazji namawiano Amerykanów do zakupu obligacji wojennych, z których zyski zasilały fundusz armii. Odwołanie się do konieczności ochrony dzieci było doskonałym sposobem nakłonienia obywateli 
Bohater, wróg, zdrajca - amerykańskie i niemieckie plakaty...

do szczodrości. Dzieci i młodzież nie stały się zatem w propagandzie amerykańskiej elementem tak istotnym i tak nadużywanym, jak w faszystowskich Niemczech. Tu pojawia się pierwsza widoczna różnica w manipulacyjnych mechanizmach propagandy obu państw. Druga, o wiele bardziej drastyczna, dotyczy sposobu ukazywania i wykorzystywania różnic rasowych.

\section{My i wrogowie}

W propagandzie amerykańskiej istotnym zabiegiem było podkreślanie wspólnego wysiłku i zaangażowania w działania wojenne czarnoskórej części społeczeństwa. Dlatego na plakatach często pojawiają się manifestacje braterstwa i bohaterskiej postawy Afroamerykanów. Merton i Lazarsfeld zwrócili uwagę na to zjawisko już w roku 1943, analizując ulotki skierowane do czarnoskórych mieszkańców Ameryki. W materiałach tych podkreślano, że faktycznie cierpią oni z powodu dyskryminacji, lecz mimo to ich prawa i możliwości odniesienia życiowego sukcesu systematycznie wzrastają. "W przeciwieństwie do tego Hitler zawsze wyrażał pogardę dla ludów kolorowych i jeżeli wygra wojnę, wszystkie zdobycze Murzynów znikną" (2002: 547). Zastosowano tutaj retoryczny chwyt polegający na przyznaniu racji co do tego, że sytuacja Afroamerykanów nie jest w USA idealna, ale $\mathrm{w}$ przypadku zwycięstwa nazistów ulegałaby ona zdecydowanemu pogorszeniu. Nie należy jednak zapominać o rasizmie realnie istniejącym $\mathrm{w}$ amerykańskim społeczeństwie. Czarnoskórzy byli potrzebni, aby zasilać szeregi armii, jednak z walką ramię $\mathrm{w}$ ramię bywało różnie:

Powiedzmy wprost: rasizm amerykański był w tamtych czasach oficjalny. Przecież Murzyni walczyli u nich w odrębnych oddziałach [...] Władze brytyjskie nie pozwalały na odrębne traktowanie białych i czarnych żołnierzy amerykańskich przez oficerów, ale armia amerykańska $\mathrm{w}$ tej sprawie nie chciała iść na żadne kompromisy (Davies 2008: 11).

Może zatem nie jest przypadkiem to, że na plakacie z napisem „United we win", białego robotnika umieszczono ponad robotnikiem czarnoskórym. Fraternizacja była raczej wymogiem sytuacji niźli dowodem na postępowość i demokratyzację US Army. 


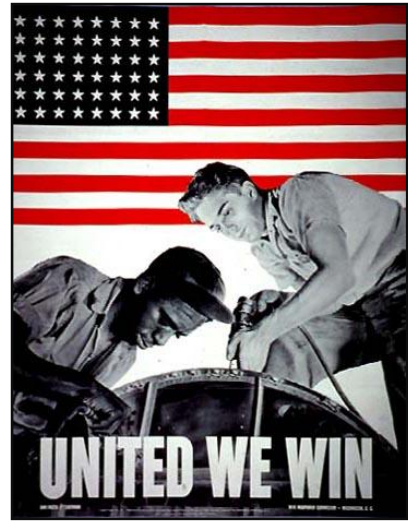

Plakat 25

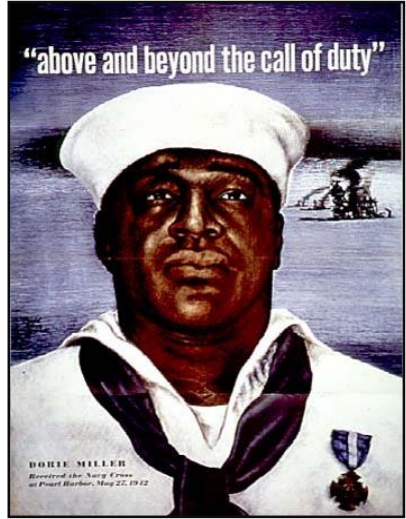

Plakat 2

Propaganda niemiecka uczyniła $\mathrm{z}$ różnic rasowych swoje główne narzędzie. Najostrzej atakowani byli Żydzi. We wspomnianym już przemówieniu minister propagandy Rzeszy podkreślał, że główni wrogowie to Żydzi, pragnący wpędzić Europę w chaos i sowieci, rozszerzający bolszewicki terror. Niemcy, a dokładnie Wehrmacht, miały stać się tarczą przeciw sowietyzacji. Odzwierciedlenie tych idei znajdujemy na plakatach. Plakat "zwycięstwo lub bolszewizm” był elementem wielkiej kampanii rozpoczętej po Stalingradzie $w$ Niemczech. W walce $z$ bolszewizmem chodziło także o starcie ras, kultur, starcie Wschodu z Zachodem. Przekonanie o międzynarodowym spisku Żydów pragnących zniszczyć zdrową niemiecką kulturę stanowiło oś propagandy faszystowskiej na długo przed wybuchem wojny.

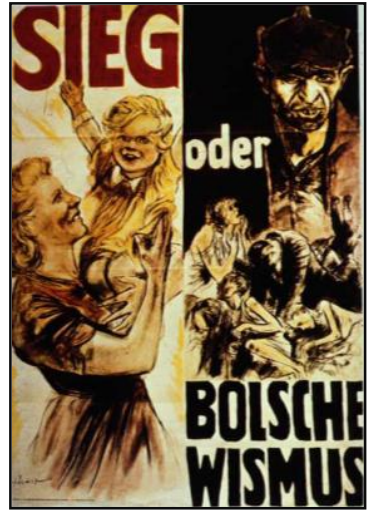

Plakat 26

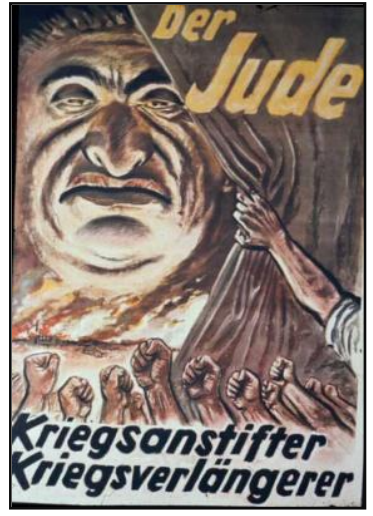

Plakat 27

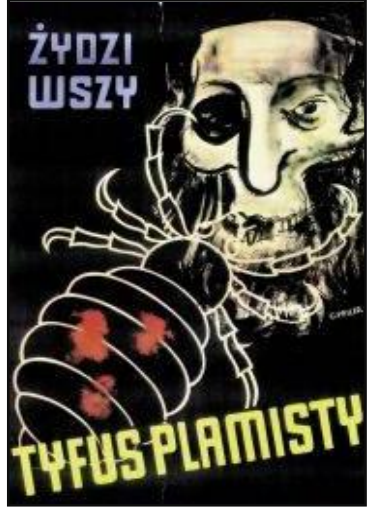

Plakat 28 
Bohater, wróg, zdrajca - amerykańskie i niemieckie plakaty...

W roku 1943 Goebbels mówił:

międzynarodowe żydostwo objawia się tutaj raz jeszcze jako wcielenie wszelkiego zła, jak sprytny demon fermentu, czynnik międzynarodowego rozkładu, niszczącego kulturę [i dalej] w żydostwie widzimy bezpośrednią groźbę dla każdego kraju [...], żydostwo jest niczym zaraźliwa choroba (Goebbels 2006: 150).

Najdobitniejszym wyrazem propagandy nienawiści był rozpowszechniany przez nazistów w okupowanej Polsce plakat głoszący hasło "Żydzi, wszy, tyfus plamisty". Wróg zostaje sprowadzony do biologicznego poziomu insekta, który roznosi śmiertelną chorobę. Wróg traktowany jako epidemia traci wszelkie ludzkie cechy. Staje się zagrożeniem, przed którym jedyną ochroną jest całkowita eliminacja. Faszystowska propaganda doprowadziła do całkowitej dehumanizacji wroga, tym samym możliwe i uzasadnione stało się ludobójstwo.

Obsesyjne porównania z pasożytami, insektami, które każdorazowo znajdują swój ekwiwalent wizualny na plakatach czy rysunkach w prasie, spełniają kilka zasadniczych funkcji. Przede wszystkim służą wzbudzeniu niechęci, odrazy wobec tak skonkretyzowanego „wroga”. Po drugie, stwarzają wrażenie, że łatwo można się go pozbyć, że wytępienie go nie stanowi żadnego problemu. Tego typu retoryka automatycznie odsuwa jakiekolwiek podejście moralne - przecież chodzi jedynie o „dezynsekcję", tępienie szkodników żerujących bezkarnie na żywej tkance narodu... (Wojciechowski 2008).

Język nienawiści przenoszony był wprost na plakaty. Na jednym z nich (plakat 27) widzimy dłoń odsłaniającą kurtynę, za nią kryje się wielka, nabrzmiała twarz Żyda, który, jak głosi hasło, podżegał do wojny, a teraz ją przedłuża (mit o światowym spisku Żydów). Rzadko kiedy mamy do czynienia $\mathrm{z}$ tak biegunowym przeciwstawieniem my - oni (wrogowie), jak w przypadku propagandy wojennej. Każda ze stron musi wciąż podtrzymywać wiarę, że walczy w słusznej sprawie, że zagrożone są podstawowe wartości, że wróg jest wszędzie i trzeba się mobilizować. Zacznijmy od ukazywania siebie, od demonstrowania własnej potęgi i sprawności bojowej. Zazwyczaj jest to obraz żołnierza reprezentującego jedną z bojowych formacji. Jego postawa musi być manifestacją siły i pewności, a wygląd powinien być na swój sposób atrakcyjny. W niemieckiej propagandzie często pojawia się rycersko-pomnikowa stylizacja. Żołnierz jest opoka, walczy z najazdem dzikich wschodnich hord, jest krzyżowcem rozszerzającym zasięg germańskiej cywilizacji. Będzie walczył aż do zwycięstwa za wszelką cenę. 


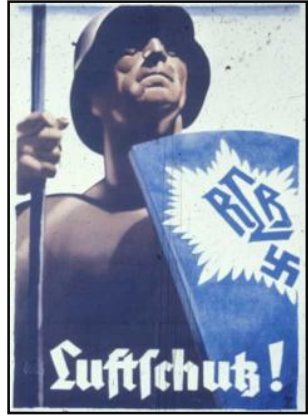

Plakat 29

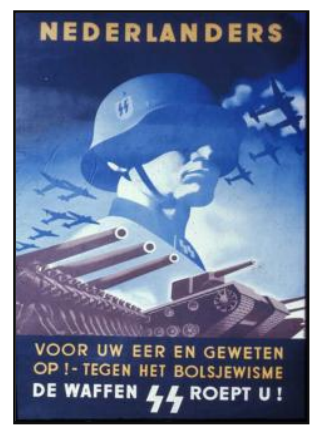

Plakat 30

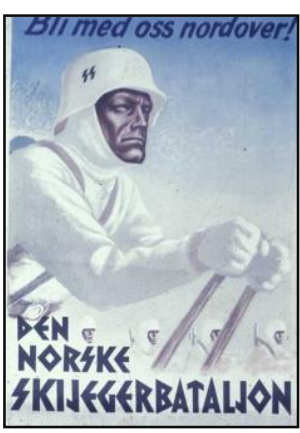

Plakat 31

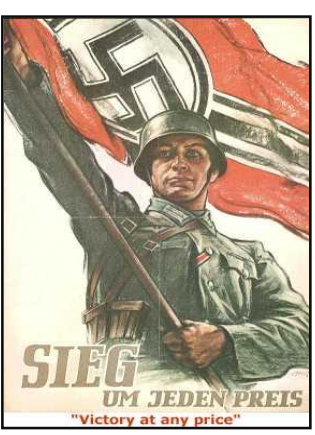

Plakat 32

Te quasi-rycerskie stylizacje pojawiały się często na plakatach zachęcających do zaciągania się w szeregi SS (plakaty 30 i 31). Bataliony i dywizje tej zbrodniczej formacji powstały $\mathrm{w}$ prawie każdym podbitym przez faszystowskie Niemcy kraju. Ideolodzy SS tworzyli mit rycerskiego zakonu, do którego przyjmowano tylko wybranych. Heinrich Himmler pragnął uczynić z formacji, którą dowodził, czarny rycerski zakon, elitarną armię najwierniejszych Pretorian. Plakaty ukazywały także inne jednostki Wehrmahtu, Kriegsmarine i Luftwaffe. Na jednym z nich umieszczono napis „piechota królową wszystkich Służb” (plakat 36).

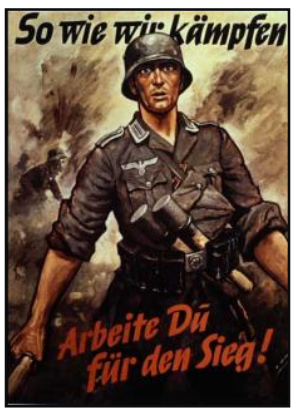

Plakat 33

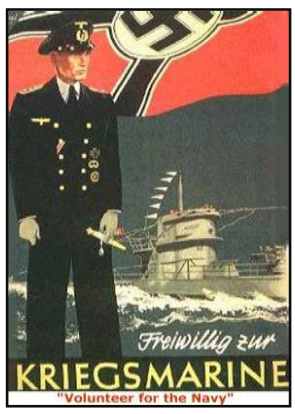

Plakat 34

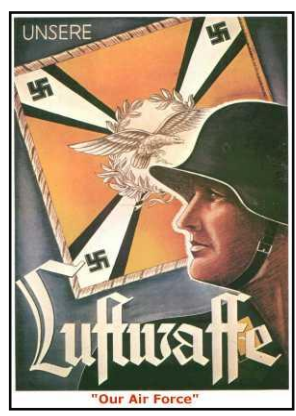

Plakat 35

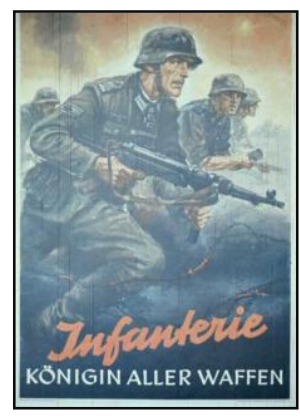

Plakat 36

Formuła ukazywania własnych jednostek wojskowych na plakatach amerykańskich była podobna. Tutaj także chodziło o ukazanie potęgi własnej armii, ale pojawił się również wątek poświęcenia i śmierci na froncie, którego w tak dosłownej formie nie znalazłem na faszystowskich posterach. Amerykańskiej propagandzie obca jest też ta specyficzna pomnikowo-rycerska stylizacja, której tak wiele pojawiało się na niemieckich plakatach. 


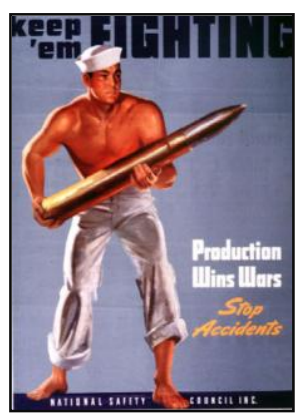

Plakat 37

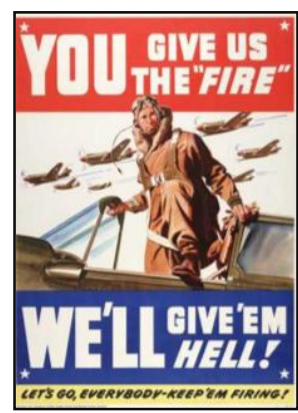

Plakat 38

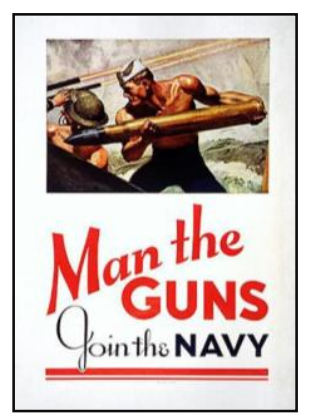

Plakat 39

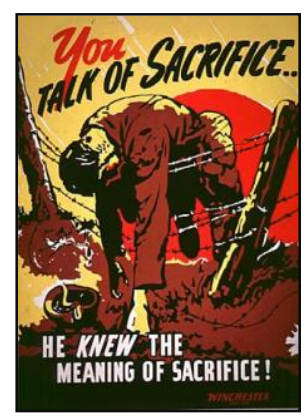

Plakat 40

Na jednym z posterów namalowano martwego żołnierza przewieszonego przez druty kolczaste i zamieszczono następujący komentarz: „Mówisz o poświęceniu. On znał znaczenie poświęcenia" (plakat 40). Podobna dosadność towarzyszyła plakatom ostrzegającym przed skutkami braku czujności i łatwowiernością. W sposobach ukazywania wroga można odnaleźć pewne uniwersalne podobieństwa. A zatem będzie to karykaturalna stylizacja, towarzyszące jej przerysowanie i dosadność. W przypadku niemieckim znamy już sposób ukazywania Żydów i bolszewików. Na posterach amerykańskich obok hitlerowców pojawiali się także wrogowie z drugiego frontu - Japończycy. W obu przypadkach chodziło o jasny komunikat o zagrożeniu i barbarzyństwie, jakie niosą ze sobą agresorzy. Wróg był bezlitosny i wszechobecny. Stałym elementem wojennej propagandy jest nieustanne podkreślanie zagrożenia, które zmusza do przeciwdziałania i mobilizacji na frontach zewnętrznych, a także wewnętrznych. Amerykanie nie stosowali tak konsekwentnie dehumanizującej propagandy, jak robili to Niemcy. Ich wrogowie na plakatach byli przerysowani, okrutni i źli, pozostawali jednak z reguły ludźmi podlegającymi moralnej ocenie.

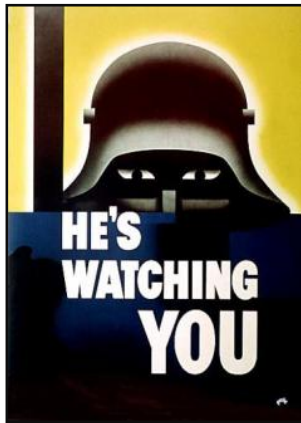

Plakat 41

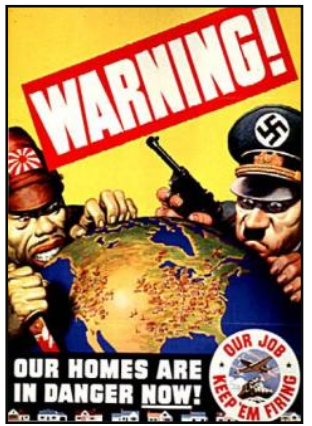

Plakat 42

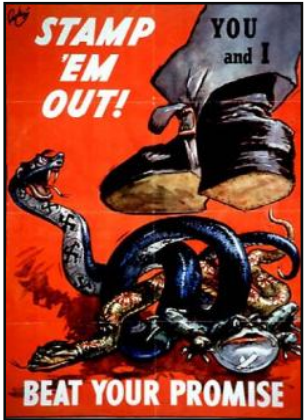

Plakat 43

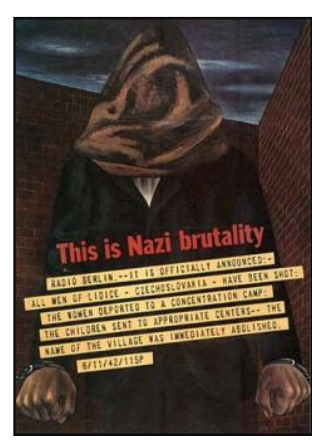

Plakat 44 


\section{Wartości i symbole}

Koncentrowano się zatem na ukazywaniu zagrożenia, na konieczności obrony i na tym, co należy zrobić z wrogiem (np. „Stamp 'Em Out”). Wskazywano także na wartości, których należy chronić. Jedna $\mathrm{z}$ amerykańskich kampanii propagandowych zainspirowana została przemówieniem prezydenta. 6 stycznia 1941 r. prezydent Roosevelt wygłosił w Kongresie USA słynne przemówienie, które do historii przeszło pod nazwą Cztery wolności. W nim to sformułował swoją ideę Ameryki, za sprawą której swobody obywatelskie i demokratyczny model państwa rozprzestrzeni się na cały świat. $\mathrm{W}$ imię tego niezbędna może okazać się konieczność przystąpienia Stanów Zjednoczonych do wojny. Prezydent sformułował cztery podstawowe sfery wolności, którymi powinien cieszyć się każdy obywatel globu. Pierwsza to wolność słowa na całym świecie i możliwość wyrażania opinii, druga to swoboda wyznaniowa każdego człowieka w każdym miejscu na świecie, trzecia to wolność ekonomiczna, dostatek pozwalający na godne życie, i wreszcie czwarta - wolność od lęku przed agresją ze stronny innego państwa. Czwarty punkt miał według Roosevelta oznaczać taką redukcję zbrojeń, aby żadne państwo nie mogło dopuścić się aktu fizycznej agresji na któregokolwiek z sąsiadów - w żadnym miejscu na świecie. Ten szlachetny projekt stworzenia bezpiecznego świata miał być odpowiedzią na dyktaturę tyranii. 32. prezydent Stanów Zjednoczonych zakończył swoje przemówienie takimi oto słowami:

Ten naród powierzył swoje przeznaczenie rękom, głowom i sercom milionów wolnych mężczyzn i kobiet i swojej wierze w wolność pod Bożym przewodnictwem. Wolność oznacza nadrzędną rolę praw człowieka na całym świecie. Udzielamy naszego poparcia tym, którzy walczą by uzyskać i utrzymać te prawa. Naszą siłą jest to, że mamy jeden wspólny cel. Dla tak wzniosłej idei nie może być innej perspektywy niż zwycięstwo (2006: 126).

Przemówienie stało się inspiracją dla rysownika Normana Rockwella do zilustrowania Czterech wolności plakatami, przedstawiającymi adekwatne sceny z życia zwykłych Amerykanów. Pomysł Rockwella bardzo przypadł do gustu władzom i tak powstała jedna $\mathrm{z}$ popularniejszych serii plakatowych. Używano ich w szeroko zakrojonej kampanii zachęcania do kupowania obligacji wojennych (podpis pod każdym rysunkiem „buy war bonds"). Plakaty w jasny i zrozumiały dla każdego Amerykanina sposób wyjaśniały 
cele wojny. Najłatwiej przecież było odwołać się do obrony tradycyjnych amerykańskich wartości, stylu życia, któremu zagroziła inwazja państw Osi. Obrona stylu życia i wartości wydaje się zresztą stałym elementem propagandy rządowej, ten sam retoryczny chwyt wykorzystał także prezydent Bush po ataku na World Trade Center. 20 września 2001 r. George W. Bush wygłosił przemówienie, w którym padły następujące słowa:

Chcę abyście trwali przy wartościach Ameryki i pamiętali, dlaczego tak wielu przybyło do niej. Walczymy w obronie naszych zasad, więc naszą pierwszą powinnością jest stosować je w życiu (2006: 351).

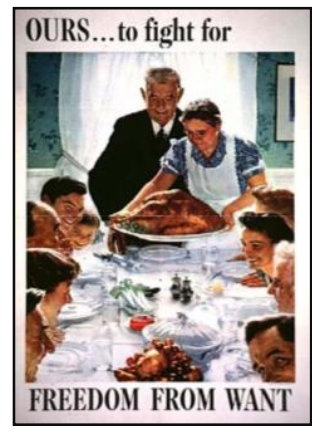

Plakat 45

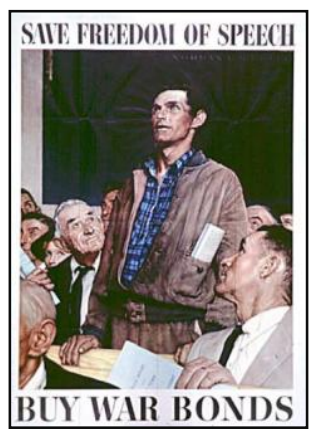

Plakat 46

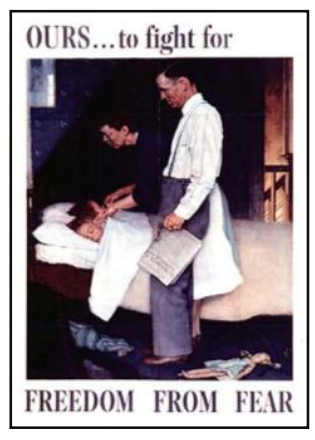

Plakat 47

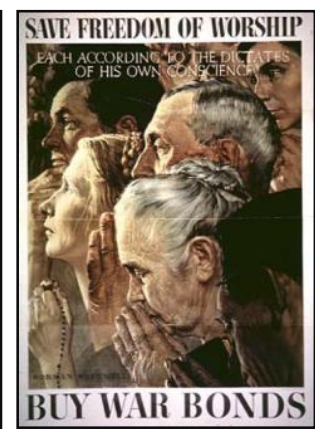

Plakat 48

Obrazując „cztery wolności” rysownik nie ukazał działań wojennych, zniszczeń czy wrogów, przedstawił wyidealizowany obraz american way of life. Kraina wolności słowa, dostatku, bezpieczeństwa oraz swobody wyznań dla wszystkich istniała tylko na plakatach i w propagandowych broszurach, była projektem, marzeniem, mrzonka, utopia, ale w przeciwieństwie do postulatów propagandy niemieckiej miała charakter propagandy pozytywnej (plakaty 45-48).

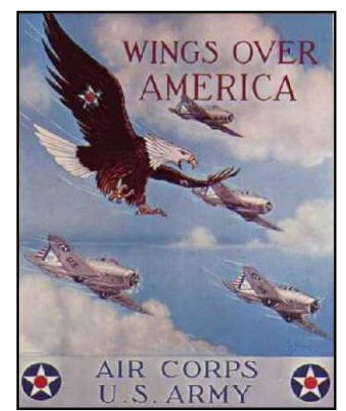

Plakat 49

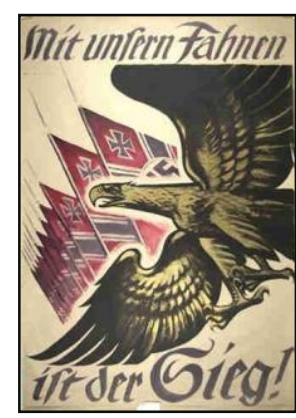

Plakat 50

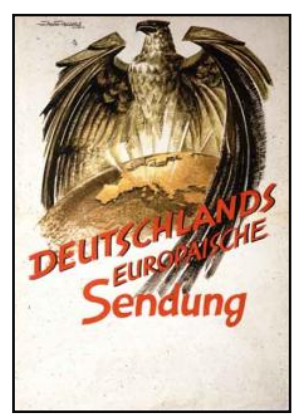

Plakat 51 
Propaganda zawsze odwołuje się do mocnych, jasnych dla wszystkich symboli. W przypadku propagandy wojennej uruchomiony zostaje szereg symboli narodowych, takich jak sztandary, flagi, emblematy. Na plakatach niemieckich najczęściej pojawiającym się symbolem była swastyka. W analizowanej grupie 30 obrazów, zaprezentowano ją 12 razy, czasami jako samoistnie funkcjonujący symbol, czasami jako element umundurowania żołnierzy. Znaczącym symbolem w obu przypadkach jest orzeł umieszczony na godłach USA i Trzeciej Rzeszy (plakaty 49-51). Oczywiście inaczej stylizowany przez Amerykanów, a inaczej przez Niemców, odnosił się do tego samego ładunku symbolicznego i nawiązań historycznych do potęgi starożytnych mocarstw. Na plakatach amerykańskich często pojawiały się narodowe barwy i gwiaździsty sztandar, choć nie tak często jak swastyki na posterach niemieckich.

Symbole służące narodowym i ideologicznym identyfikacjom używane były wzajemnie przez obie strony konfliktu w celu czytelnego wskazania wroga. Amerykanie posługiwali się swastykami, które symbolizowały zło, niebezpieczeństwo i nazistowską brutalność (plakat 53). Podobną funkcję spełniały narodowe barwy Japonii, które stały się na jednym z rysunków tarczą dla amerykańskich bomb (plakat 54). Niemcy także korzystali z symboli swoich przeciwników, ukazywali ich jako barbarzyńców zagrażających Europie. Na jednym z plakatów widzimy monstrualnego robota depczącego jedno z europejskich miast (plakat 55). $\mathrm{Na}$ jego ramieniu rysownik umieścił cheerleaderkę trzymającą $\mathrm{w}$ dłoni gwieździsty sztandar.

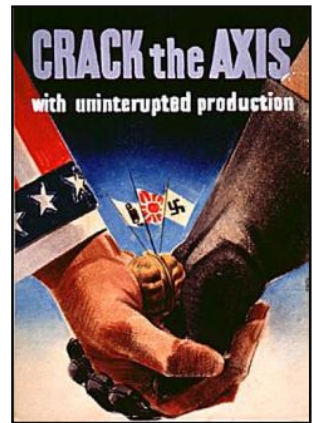

Plakat 52

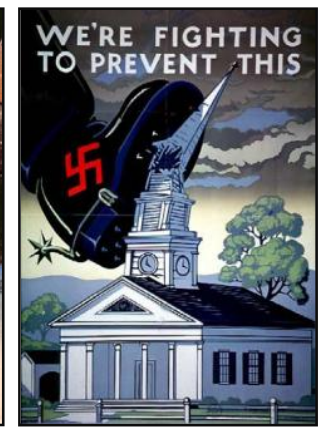

Plakat 53

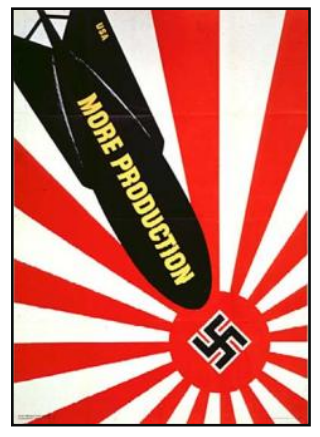

Plakat 54

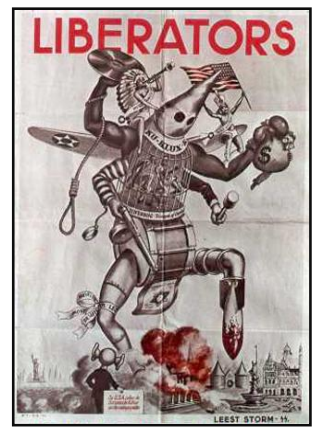

Plakat 55

Symbole i alegorie stanowią główne elementy konstrukcyjne wojennych plakatów. Umożliwiają one przekazanie skondensowanej treści przy użyciu niewielkiej liczby elementów. Rzadko jednak działają one 
samodzielnie, w oderwaniu od słownego sloganu. Kod wizualny zyskuje konieczną do tego, aby był skuteczny, argumentację werbalną. Przekaz jest najsilniejszy wówczas, gdy systemy komunikacji słownej i obrazowej zostają sprzęgnięte $\mathrm{w}$ spójnym działaniu. $\mathrm{W}$ wybranej przez mnie grupie plakatów nie ma ani jednego, na którym obraz nie współgrałby ze słowem. Slogan jest jednym z najważniejszych elementów manipulacyjnych reklamy i propagandy. Dobrze dobrany zestaw słów może mieć ogromną moc sprawczą. Komunikat musi być prosty w stylu: „I wont you for U.S Army”, „We can do it”, „United we win” lub „Ein Volk, ein Reich, ein Führer". Sam slogan w oderwaniu od obrazu, według J. Austina i J. Searle'a, staje się werdyktem, poleceniem, zobowiązaniem, określeniem postawy, stwierdzeniem, ekspresją lub deklaracją (Albin 2002: 172). Na plakatach wojennych dominuje formuła polecenia (,Join the Navy", "Gerade Du") oraz deklaracje („Sieg um jeden Preis", „We can do it"). Oczywiście obecne są także wszelkie inne formy sloganów, czasami łączące dwie funkcje, np. stwierdzenia i przestrogi („He is watching you”). Napisy najczęściej umieszczano na górze lub na dole plakatu, tak aby pozostawić środkową część na obraz. Odstępstw od tej zasady jest bardzo niewiele. Tekst rzadko przekracza długość zdania, co jest typowe dla zwartej struktury sloganu. Widocznie różnią się stosowane przez Amerykanów i Niemców kroje czcionek. Szczególnie charakterystyczne są różne warianty gotyckiego liternictwa na nazistowskich posterach. $\mathrm{Na}$ ich tle czcionki wykorzystywane w Ameryce wydają się bardzo proste, czytelne, nowoczesne, zbliżające się do stylu Times New Roman. Może być to wyrazem myślenia pragmatycznego - prosta czcionka jest bardziej czytelna, ale i manifestowaniem swojej kultury. W przypadku Niemców, gotycki krój pisma mógł być nawiązywaniem do tradycji i mitów, podkreśleniem własnej odrębności i wspomnianych już quasi-rycerskich konotacji. Kolejną ważną kategorią analityczną jest kolorystyka stosowana na plakatach. Pierwsze wrażenie $\mathrm{z}$ pobieżnego porównania obu zestawów skłania do wniosku, że plakaty niemieckie wykonywano w ciemniejszych barwach, dominują na nich różne odcienie brązu, czerwień, czerń i kolor szaroniebieski. Czerń i czerwień w III Rzeszy stały się kolorami narodowymi, wszechobecnymi na sztandarach, mundurach, budynkach i oznakowaniu sprzętu bojowego. Na posterach z USA pojawia się więcej kolorów, w tym niemalże nieobecny na niemieckich plakatach kolor żółty. Nie oznacza to jednak wcale, że faszystowskie postery zawsze są ciemne i ponure, a amerykańskie żywe w kolorystyce i jasne. Amerykańscy plakaciści śmielej zestawiali jasne i ciemne barwy, uzyskując 
w ten sposób większą dynamikę kolorystyczną. Z kolei autorzy z III Rzeszy stosowali bardziej stonowaną paletę barw, w której czerwień była $\mathrm{z}$ reguły jedynym mocniejszym akcentem.

\section{Walka na wielu frontach}

W zestawie plakatów pochodzących z USA ujawniła się jeszcze jedna dość licznie reprezentowana grupa, o której należy wspomnieć. Są to postery zachęcające do oszczędzania surowców i paliw. Jeden z nich ukazuje mężczyznę samotnie jadącego samochodem. Obok niego siedzi pasażer - zakreślony białym konturem fantom wodza III Rzeszy, a wszystko wyjaśnia napis „Kiedy jedziesz sam, jedziesz z Hitlerem” (plakat 56). Sposobem na uniknięcie tego typu rozrzutności było wstępowanie do klubów wspólnego podróżowania samochodami (car-sharing club). W ciekawy sposób rozwiązano graficznie kolejny z serii tego typów plakatów. "Straty pomagają wrogowi" - głosi slogan, a rysunek ukazuje głowę Hitlera ułożoną z drobnych biurowych, zmarnowanych przedmiotów (plakat 57). Kolejne dwa postery z tej kategorii przestrzegają przed podróżami, których odbycie nie jest absolutnie konieczne (plakat 58) i przed marnotrawieniem tłuszczów, które mogą zostać wykorzystane w produkcji materiałów wybuchowych (plakat 59). Pośród plakatów niemieckich także pojawia się podobny wątek. Jednak $\mathrm{w}$ wybranej przeze mnie grupie reprezentowany jest on jedynie przez jeden poster, zachęcający do oddawania starych ubrań i obuwia na potrzeby frontu.

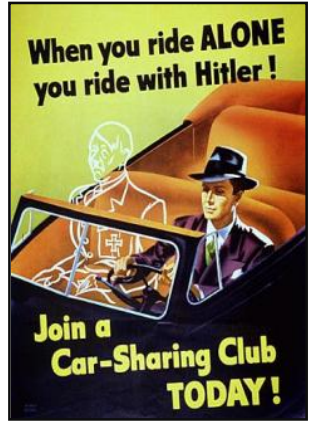

Plakat 56

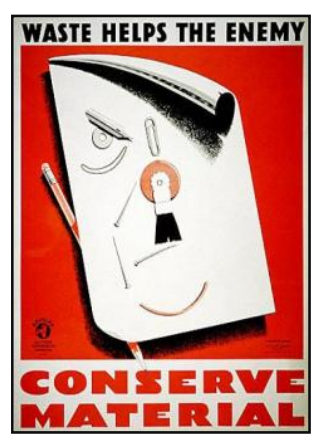

Plakat 57

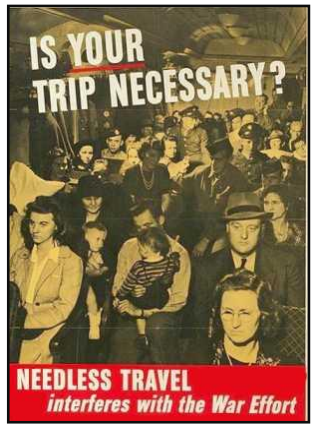

Plakat 58

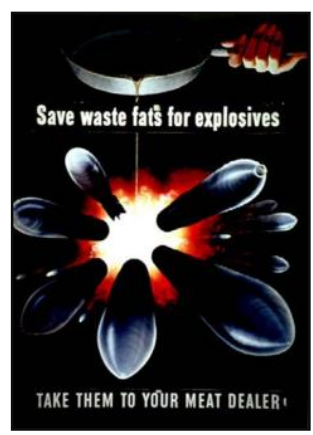

Plakat 59 
Oddzielnym tematem, który także należałoby poddać wnikliwej analizie, jest obszar propagandy zwróconej w stronę polityki żywieniowej. W czasie wojny oszczędzać należy nie tylko to, co jest niezbędne dla sprawnego działania przemysłu zbrojeniowego, ale także pożywienie, które przede wszystkim zapewnić trzeba tym, którzy walczą. Zagadnienie to jedynie sygnalizuję poniższym plakatem skierowanym $\mathrm{w}$ czasie trwania I wojny światowej do amerykańskiej Polonii. Wykorzystanie portretu Tadeusza Kościuszki i przywołanie Kazimierza Puławskiego, dwóch bohaterów zarówno polskich, jak i amerykańskich doskonale wpisuje się w propagandową retorykę walki o wspólną sprawę (plakat 60).

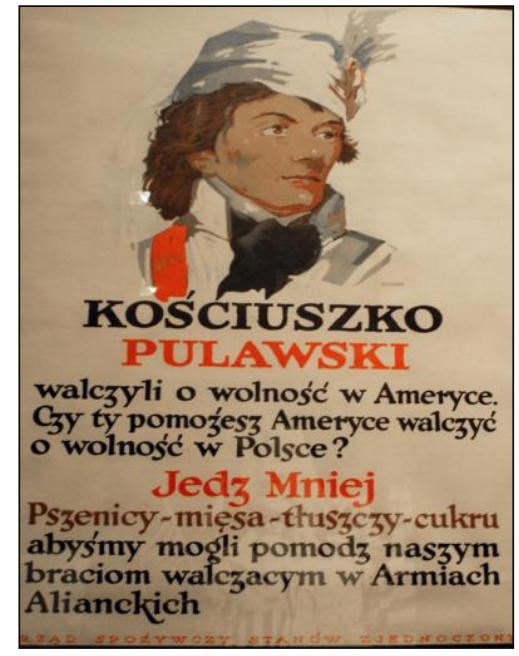

Plakat 60

\section{Podsumowanie}

Na plakatach wojennych wyraźnie ujawniają się ślady realizowanej przez faszystów biopolityki, która przyjęła formę dwóch eugenicznych zasad. Pierwsza $z$ nich polegała na selekcji i eliminacji przedstawicieli "słabych i bezwartościowych" ras. Druga miała wspomagać proces "namnażania” jednostek „,wartościowych pod względem biologicznym”. Chodziło zatem o ochronę przed "wnikaniem obcej krwi” z jednej strony, z drugiej zaś o zachowanie „oryginalności rasowej” (Lemke 2010: 20). Na- 
rodziny biopolityki w swoich wykładach analizował M. Foucault. Dla francuskiego filozofa kluczowym momentem $\mathrm{w}$ jej rozwoju jest pojawienie się rasizmu:

Czym jest bowiem rasizm? Jest to przede wszystkim sposób wprowadzenia pewnego cięcia do tej dziedziny życia, którą zajęła się władza: cięcia między tym co powinno żyć, i tym, co powinno umrzeć (1998: 252).

Ujawnienie się hierarchii ras umożliwiło władzy podzielenie populacji na podgrupy, a dalej także na eliminacje grup uznanych za gorsze. $\mathrm{W}$ istocie oznacza to, że śmierć innego, zniszczenie niższej, gorszej rasy czyni życie zdrowszym i czystszym (Foucault 1998: 253). Jest to zatem relacja nie tyle militarna czy polityczna, ale właśnie biologiczna, polegająca na wyeliminowaniu zagrożenia zdrowia własnej rasy. I dlatego właśnie Foucault dowodzi, że rasizm jest niezbędny dla realizowania celów biowładzy, ponieważ uzasadnia akceptowalność skazywania przedstawicieli innych ras na śmierć (nie zawsze musi ona oznaczać całkowitą fizyczną eliminację, może być to społeczna marginalizacja, wykluczenie, zmuszenie do emigracji itd.). „Z chwila, gdy państwo funkcjonuje według modelu biowładzy, państwowa funkcja zabijania może być spełniona tylko przez rasizm" (Foucault 1998: 253). Nazizm rozwinął i upowszechnił na masową skalę nowe zbrodnicze technologie dyscyplinarne oraz koncepcje biowładzy. Doprowadziło to do sytuacji bez precedensu w historii. „Mamy tu państwo absolutnie rasistowskie, państwo absolutnie zbrodnicze i państwo absolutnie samobójcze" (Foucault 1998: 257). $\mathrm{Z}$ jednej strony III Rzesza realizowała program „ostatecznego rozwiązania" (absolutna zbrodnia), z drugiej strony Hitler, kiedy wojna była już przegrana, postulował zniszczenie logistycznej i przemysłowej infrastruktury własnego państwa (samounicestwienie). Faszystowski program osiągania celów politycznych nie zakładał jedynie eliminacji innych ras, ale także narażenie własnej rasy na ryzyko śmierci:

Tylko takie uniwersalne narażenie całej populacji na śmierć będzie mogło ją efektywnie ukonstytuować jako wyższą rasę i definitywnie ją odrodzić w stosunku do innych ras, które zostaną całkowicie wyeliminowane lub ostatecznie podporządkowane (Foucault 1998: 256).

Dlatego właśnie na nazistowskich posterach odnajdujemy zarówno nawoływania do bezwzględnego eksterminowania „niższych” ras, jak i do walki, która - angażując cały naród - doprowadzi do całkowitego i ostatecznego zwycięstwa. 
Bohater, wróg, zdrajca - amerykańskie i niemieckie plakaty...

Wojenne postery odgrywają różne role: ostrzegają nakłaniają przypominają. Każda $\mathrm{z}$ tych funkcji realizowana jest za pomocą innego zestawu obrazów, wizualnych alegorii i symboli. Do mężczyzn mających iść na front kieruje się wizerunki herosów, obrońców ojczyzny lub walecznych zdobywców. Do kobiet mają trafić obrazy pracowitych i świadomych swojej roli bohaterek drugiej linii frontu, przejmujących zadania walczących mężczyzn. Odpowiednie sygnały wysyła się do przedstawicieli innych ras w zależności od tego, czy chce się ich przerazić, czy też zachęcić do współpracy. W propagandzie wojennej jest też miejsce dla dzieci i młodzieży. Tu znowu wszystko zależy od polityki prowadzonej przez rządzących, od systemu politycznego i od wizji tego, jak przebiegać ma wojna. Niemiecki plan wojny totalnej nie oszczędzał najmłodszych, podczas gdy propaganda amerykańska kładła nacisk na konieczność ich ochrony. Dyktatura i demokracja posługują się podobnymi w wielu momentach formami propagandy i konstruują podobne przekazy. Zarówno plakaty niemieckie, jak i amerykańskie zachęcają do walki za ojczyznę, do wzmożonego wysiłku, do czujności, do oszczędzania deficytowych surowców. Zasadnicza różnica tkwi w stojącej za propagandą ideologii i w celach, jakim ma ona służyć. Faszystowskie Niemcy posługiwały się propagandą w stylu państw totalitarnych, która większość swoich przekazów poświęcała wodzowi lub jego niezwyciężonej armii. Społeczeństwo staje się w takich okolicznościach masa, ślepo zapatrzoną w swojego przywódcę, ubezwłasnowolnionym tłem dla głównego aktora. Dlatego deklaracje "Zwycięstwo za wszelką cenę" i ogłoszenie planu wojny totalnej całkowicie wpisują się w logikę tego systemu. W państwie demokratycznym dominujące akcenty rozkładane są zupełnie inaczej. Częściej pojawiają się przekazy będące wyrazem troski o społeczeństwo, jego wolność i dobrobyt (cykl plakatów Cztery wolności). Niespotykane sa, częste na niemieckich plakatach, manifestacje nienawiści rasowej. Wręcz przeciwnie, kolorowi obywatele, stają się nagle ważni i potrzebni. Podkreśla się ich odwagę i poświęcenie na froncie. Pamiętajmy jednak, że problem rasizmu w USA istniał i nie zakończył się wraz z II wojną światową. Wtedy jednak potrzebni byli żołnierze, a kolor ich skóry nie stanowił sprawy pierwszoplanowej. Niezależnie od tego, jaką propagandę poddamy analizie, musimy pamiętać, że podstawowa a może jedyną jej funkcją jest perswazja. Opiera się ona na zestawie technik, gestów, ikon i symboli, który $\mathrm{w}$ rezultacie jest dość jednorodny. W przypadku propagandy wojennej zestaw ten dodatkowo zostaje ujednolicony i zredukowany do kilku dominujących figur - bohatera, zdrajcy lub wroga. 


\section{Bibliografia}

Albin, K., (2002), Reklama. Przekaz, odbiór, interpretacja. Warszawa: PWN.

Bauman, Z., (1995), Ciało i przemoc w obliczu ponowoczesności. Toruń: UMK.

Bush, W. G., (2006), Po ataku 11 września, [w:] Wielkie mowy historii. Od Kennedy'ego do Ratzingera, red. M. Gumkowski. Warszawa: Polityka.

Davies, N., (2008), II wojna. Wydanie poprawione, „Gazeta Wyborcza. Gazeta na Święta”, 31.10 - 2.11: 9-11.

Foucault, M., (1998), Trzeba bronić społeczeństwa. Wykłady w Collège de France, 1976. Warszawa: Wydawnictwo KR.

Goebbels, J., (2006), Zatem powstań narodzie i niech rozpęta się burza, [w:] Wielkie mowy historii. Od Hitlera do Eisenhowera, red. M. Gumkowski. Warszawa: Polityka.

Lazarsfeld, P. K., Merton, K. R., (2002), Teoria socjologiczna i struktura społeczna. Warszawa: PWN.

Lemke, T., (2010), Biopolityka. Warszawa: Wydawnictwo Sic!

Pratkanis, A., Aronson, E., (2003), Wiek propagandy. U̇̇ywanie i nadużywania perswazji na co dzień. Warszawa: PWN.

Rose, G., (2006), Visual Methodologies. An Introduction to the Interpretation of Visual Materials. London: Sage.

Rose, G., (2010), Interpretacja materiałów wizualnych. Krytyczna metodologia badań nad wizualnością. Warszawa: PWN.

Roosevelt, D. F., (2006), Cztery wolności, [w:] Wielkie mowy historii. Od Hitlera do Eisenhowera, red. M. Gumkowski. Warszawa: Polityka.

Wojciechowski, Ł. M., (2008), „Der Jude” - „Ten Żyd” - geneza, funkcjonowanie $i$ siła trwania wizerunku, http://www.obieg.pl/artmix/artmix14_02.php [dostęp: 2.11.2008].

http://www.archives.gov

http://www.calvin.edu/academic/cas/gpa/posters2.htm

\section{Informacje na temat wykorzystanych w pracy plakatów:}

\section{Plakat 1}

United States Office of Facts and Figures, 1942

Tytuł: Pvt. Joe Louis says..., "We're going to do our part and we'll win because we're on God's side"

\section{Plakat 2}

Autor: David Stone Martin, U.S. Government Printing Office or the Office of War Information, NARA Still Picture Branch, Washington, D.C., 1943

Tytut: Above and beyond the call of duty

\section{Plakat 3}

Autor: nieustalony, 1938

Tytuł: Ein Volk, ein Reich, ein Führer

plakat drukowany po anschlussie Austrii 
Bohater, wróg, zdrajca - amerykańskie i niemieckie plakaty...

\section{Plakat 4}

Autor: nieustalony, 1943

Tytut: Adolf Hitler is der Sieg!

plakat drukowany po niemieckiej klęsce pod Stalingradem

\section{Plakat 5}

American Industries War Production Incentives, NARA Still Picture Branch, 1942

Tytuł: Get hot - keep moving

\section{Plakat 6}

Autor: nieustalony, 1943

Tytuł: Schufft Waffen für die Front

\section{Plakat 7}

Royal Typewriter Company for the U.S. Civil Service Commission, b.d.

Tytul: Victory waits on your fingers

\section{Plakat 8}

Autor: nieustalony, 1941

Tytuł: Kreis-Tag Der NSDAP

plakat reklamujący zjazd członków NSDAP w 1941 r.

\section{Plakat 9}

Autor: Franz Würbel, 1936

Tytuł: Mütter Kämpft für eure Kinder!

\section{Plakat 10}

Autor: nieustalony, b.d.

Tytuł: I'am making bombs and buying bonds!

kanadyjski plakat z okresu 1939-1945

\section{Plakat 11}

Autor: Alfred Palmer, Prints and Photographs Division, 1943

Tytuł: The more women at work the sooner we win!

\section{Plakat 12}

Autor: J. Howard Miller, Westinghouse War Production Co-Ordinating Committee, 1943 Tytuł: We can do it!

\section{Plakat 13}

Autor: Lavrance Wilbur, Government Printing Office for the War Manpower Administration, 1944

Tytuł: Longing won't bring him back sooner..., Get a war job!

\section{Plakat 14}

Autor: Victor Keppler, NARA Still Picture Branch, 1944

Tytuł: Wanted! For Murder

\section{Plakat 15}

Autor: Herbert Morton Stoops, Office of War Information, 1944

Tytul: Careless talk ... got there first 


\section{Plakat 16}

Autor: Wesley, Printing Office for the Office of Price Administration, NARA Still Picture Branch, 1943

Tytuł: ...because somebody talked!

\section{Plakat 17}

Autor: Siebel, Printing Office for the Office of Price Administration, NARA Still Picture Branch, 1942

Tytuł: Someone talked!

\section{Plakat 18}

Autor: nieustalony, 1933

Tytuł: Kinder, was wißt Ihr vom Führer

okładka książki napisanej przez H. Morgenrotha M. Schmidta, wydawca: Franz Schneider Verlag, Lipsk, 1933

\section{Plakat 19}

Autor: nieustalony, 1940

Tytuł: Jugend dient dem Führer

plakat werbunkowy organizacji Hitlerjugend

\section{Plakat 20}

Autor: nieustalony, 1935/1936

Tytuł: Alle 10jährigen zu uns

plakat werbunkowy organizacji Hitlerjugend, 1935/1936

\section{Plakat 21}

Autor: Ludwig Hohlwein, 1937

Tytuł: Bund Deutscher Mädel in der Hitlerjugend

plakat żeńskiej organizacji Bund Deutscher Mädel znajdującej się w strukturach Hitlerjugend

\section{Plakat 22}

Autor: nieustalony, b.d.

Tytuł: Gerade Du!

plakat rekrutacyjny SS skierowany do członków Hitlerjugend

\section{Plakat 23}

Autor: Lawrance B. Smith, Printing Office for the U.S. Treasury, NARA Still Picture Branch, 1942

Tytul: Don't let the shadow touch them. Buy war bonds

\section{Plakat 24}

Autor: G. K. Odell, United States Office of Facts and Figures, NARA Still Picture Branch, 1942-1945

Tytuł: Keep these hands off! Buy victory bonds

\section{Plakat 25}

Autor: Alexander Liberman, Government Printing Office for the War Manpower Commission, NARA Still Picture Branch, 1943

Tytul: United we win 
Bohater, wróg, zdrajca - amerykańskie i niemieckie plakaty...

\section{Plakat 26}

Autor: nieustalony, 1943

Tytuł: Sieg oder Bolschewismus

nazistowski plakat antyżydowski

\section{Plakat 27}

Autor: Hans Schweitzer, 1943 lub 1944

Tytuł: Der Jude. Kriegsanstifter. Kriegsverlängerer

plakat antyżydowski

\section{Plakat 28}

Autor: nieustalony, 1942

Tytuł: Żydzi. Wszy. Tyfus Plamisty

niemiecki plakat antysemicki

\section{Plakat 29}

Autor: nieustalony, b.d.

Tytuł: Luftschuß!

plakat rekrutacyjny niemieckiej służby przeciwlotniczej

\section{Plakat 30}

Autor: nieustalony, b.d.

Tytuł: Nederlanders. De Waffen SS Roept U!

plakat rekrutacyjny oddziałów SS w Holandii

\section{Plakat 31}

Autor: nieustalony, b.d.

Tytuł: Den Norske Skijegerbatalion

plakat rekrutacyjny oddziałów SS w Norwegii

\section{Plakat 32}

Autor: nieustalony, prawdopodobnie 1943

Tytuł: Sieg um jeden Preis

\section{Plakat 33}

Autor: nieustalony, 1942

Tytuł: Arbeite Du für den Sieg!

\section{Plakat 34}

Autor: nieustalony, b.d.

Tytuł: Freiwillig zur Kriegsmarine

plakat rekrutacyjny niemieckiego Kriegsmarine

\section{Plakat 35}

Autor: nieustalony, b.d.

Tytuł: Unsere Luftwaffe

plakat niemieckich sił lotniczych Luftwaffe

\section{Plakat 36}

Autor: nieustalony, 1942

Tytuł: Infanterie. Königin aller Waffen

plakat niemieckich oddziałów "piechoty" 


\section{Plakat 37}

National Safety Council, Inc., NARA Still Picture Branch, b.d.

Tytuł: Keep 'em fighting. Production wins wars

\section{Plakat 38}

Oldsmobile Division, General Motors Corporation, b.d.

Tytuł: You give us the "fire". We'll give 'em hell!

\section{Plakat 39}

Autor: McClelland Barclay, Navy Recruiting Bureau, NARA Still Picture Branch, 1942 Tytuł: Man the Guns. Join the Navy

\section{Plakat 40}

Winchester, NARA Still Picture Branch, b.d.

Tytuł: You talk of sacrifice...

\section{Plakat 41}

Autor: Glen Grohe, NARA Still Picture Branch, 1942

Tytut: He's watching you

\section{Plakat 42}

General Motors Corporation, NARA Still Picture Branch, 1942

Tytuł: Warning! Our homes are in danger now!

\section{Plakat 43}

Office of Facts and Figures, NARA Still Picture Branch, 1942

Tytuł: Stamp'em out!

\section{Plakat 44}

Autor: Ben Shahn, Printing Office for the Office of Price Administration NARA Still Picture Branch, 1942

Tytuł: This is Nazi brutality

\section{Plakat 45}

Autor: Norman Rockwell, Government Printing Office for the Office of War Information, NARA Still Picture Branch, 1943

Tytuł: Ours... to fight for. Freedom from want

\section{Plakat 46}

Autor: Norman Rockwell, Government Printing Office for the Office of War Information, NARA Still Picture Branch, 1943

Tytuł: Save freedom of speech. Buy war bonds

\section{Plakat 47}

Autor: Norman Rockwell, Government Printing Office for the Office of War Information, NARA Still Picture Branch, 1943

Tytuł: Ours... to fight for. Freedom from fear

\section{Plakat 48}

Autor: Norman Rockwell, Government Printing Office for the Office of War Information, NARA Still Picture Branch, 1943

Tytut: Save freedom of worship. Buy war bonds 
Bohater, wróg, zdrajca - amerykańskie i niemieckie plakaty...

\section{Plakat 49}

Autor: Tom B. Woodburn, UNT Libraries Government Documents Department, 1939

Tytuł: Wings over America. Air Corps U.S. Army

\section{Plakat 50}

Autor: nieustalony, 1940

Tytuł: Mit unsern Fahnen ist der Sieg

\section{Plakat 51}

Autor: nieustalony, 1942

Tytuł: Deutschlands europäische Sendung

\section{Plakat 52}

Autor: Charles Allen, NARA Still Picture Branch, b.d.

Tytul: Crack the Axis

\section{Plakat 53}

Autor: C. R. Miller, Think America Institute, Kelly Read \& Co., NARA Still Picture Branch, b.d.

Tytul: We're fighting to prevent this

\section{Plakat 54}

Autor: Zudor, Government Printing Office for the War Production Board, NARA Still Picture Branch, b.d.

Tytuł: More production

\section{Plakat 55}

Autor: nieustalony, 1944

Tytuł: Liberators

niemiecki plakat antyamerykański

\section{Plakat 56}

Autor: Weimer Pursell, Printing Office for the Office of Price Administration, NARA Still Picture Branch, 1943

Tytul: When you ride alone you ride with Hitler!

\section{Plakat 57}

Autor: Vanderlaan, Douglas Aircraft Company, NARA Still Picture Branch, 1943

Tytuł: Waste helps the enemy. Conserve material

\section{Plakat 58}

Office of Defense Transportation, 1943

Tytuł: Is your trip necessary?

\section{Plakat 59}

Autor: Henry Koerner, Government Printing Office for the Office of War Information, NARA Still Picture Branch, b.d.

Tytul: Save waste fats for explosives

\section{Plakat 60}

Autor: nieustalony, b.d.

Tytuł: Kościuszko. Pulawski

plakat z okresu I wojny światowej 